Niepełnosprawność. Dyskursy pedagogiki specjalnej

\title{
Dagmara Kubiak
}

pedagogika specjalna

Uniwersytet Gdański

\section{Metoda Numicon w nauczaniu uczniów pełnosprawnych i ze specjalnymi potrzebami edukacyjnymi w świetle badań}

Wprowadzenie do tekstu jest teoretyczną podstawą metody Numicon. Kluczową treścią tekstu jest prezentacja brytyjskich i polskich badań ewaluacyjnych systemu Numicon. Brytyjskie badania pokazują ilościowe wyniki postępów uczniów w zakresie matematyki oraz obserwacje nauczycieli pracujących metodą Numicon. Polskie badania to projekt, w ramach którego badano doświadczenia trzech polskich nauczycieli wykorzystujących metodę Numicon. Jako metoda badawcza został wykorzystany wywiad narracyjny.

Słowa kluczowe: Numicon, edukacja matematyczna, system multisensoryczny

\section{Numicon Method in education of children with and without special educational needs. Research report}

The introduction to the text is a theoretical basis of the Numicon method. The key content of the text is a presentation of British and Polish research on evaluating the Numicon system. The British quantitative research has shown the results of children's number skills in mathematics and the observations of teachers using the Numicon as a tool. The Polish study, employing the narrative interview as a research method, explored the experience of three Polish teachers who use Numicon in teaching practice. The findings of a research pointed out two areas: the advantages and disadvantages of the Numicon method.

Keywords: Numicon, maths teaching, multi-sensory system

\section{Wprowadzenie: metoda Numicon jako konstruktywistyczna ścieżka w dydaktyce edukacji matematycznej}

Matematyka jest nieodłącznym elementem życia każdego człowieka, a znajomość jej podstaw jest niezbędna do codziennego, prawidłowego funkcjonowania. Ze względu na tak ważną rolę matematyki, która w pewien sposób warunkuje 
rozwój i przyszłe funkcjonowanie dziecka, edukacja matematyczna jest niezwykle istotna i jawi się jako ogromne wyzwanie stawiane przed nauczycielami. Jednym z dostępnych rozwiązań metodycznych jest system Numicon. Tekst ten dotyczy zarówno podstaw teoretycznych metody Numicon, jak i przeglądu dotychczasowych badań ewaluacyjnych systemu na gruncie brytyjskiej i polskiej edukacji.

Rozpoczynając poznanie metody Numicon od umiejscowienia jej w przestrzeni dydaktyki matematyki, warto przyjrzeć się jej genezie i podstawowym założeniom. System Numicon został stworzony w latach dziewięćdziesiątych ubiegłego wieku. Początkowo był on projektem stworzonym przez nauczycieli z jednej z angielskich szkół podstawowych [Tacon, Atkinson, Wing 2004]. Innowacją w projekcie miało być wykorzystanie metody multisensorycznej. Wspomniani wcześniej nauczyciele Ruth Atkinson i Romey Tacon podjęli wspólpracę z Uniwersytetem Brighton School of Education i rozpoczęli projekt $\mathrm{w}$ ramach Teacher Training Agency. Przedstawicielem Uniwersytetu Brighton był starszy wykładowca z Instytutu Edukacji Matematycznej - doktor Tony Wing, który objął projekt wsparciem merytorycznym i obecnie uznawany jest za twórcę metody. Sami autorzy określają metodę jako: „multisensoryczne podejście do nauczania arytmetyki, wykorzystujące ustrukturyzowane wzory rozwijające rozumienie liczb i zależności między nimi [Wing, Tacon 2007, s. 22]. Za przesłankę do wyboru tej formy nauczania twórcy uznają abstrakcyjność pojęć liczbowych i chęć urzeczywistnienia ich w narzędziach wykorzystywanych do nauki matematyki. Zakładają, że pozwoli to dzieciom zobaczyć zależności między liczbami i ułatwi rozwój i tworzenie ich reprezentacji w umyśle. Podzielenie metody na małe kroki uzasadniają zbyt wysoką abstrakcyjnością i kompleksowością liczb. Ponadto duże nadzieje pokładają w pobocznych efektach, jakie metoda ma przynieść - podniesieniu poziomu samooceny u uczniów, w szczególności tych, którzy do tej pory nie odnosili sukcesów w zakresie matematyki [Wing, Tacon 2007, s. 22-23]. W opracowanym przez zespół naukowców z Uniwersytetu Cambridge ramowym programie nauczania matematyki określono 6 etapów obejmujących podstawowy poziom edukacji matematycznej. W każdym z nich wyróżniono pięć obszarów tematycznych: liczby, geometria, pomiar, obsługa danych i rozwiązywanie problemów. Umiejętności, które dziecko zdobywa na poszczególnych etapach, wyszczególnione zostały w publikacji „Cambridge Primary. Mathematics Curriculum Framework" [2011]. Warto podkreślić, iż metoda dostosowana została do obowiązującej na terenie Anglii podstawy programowej - National Strategies i stosowana jest również jako jedna $\mathrm{z}$ strategii $\mathrm{w}$ programie interwencyjnym Wave 3 dla dzieci z dyskalkulią.

U podstaw konstrukcji i rozwiązań metodycznych każdej metody leżą jej założenia teoretyczne. Jednym z podstawowych obszarów rozważań teoretycznych są teorie uczenia się, które przekładają się bezpośrednio na styl nauczania, 
a także na dobór narzędzi i środków dydaktycznych. Obecnie wyróżnianymi teoriami, które odcisnęły znaczące piętno w ewolucji pedagogiki jako dziedziny naukowej, są behawioryzm, kognitywizm i konstruktywizm. Z perspektywy metody Numicon kluczową teorią uczenia się jest konstruktywizm. Konstruktywizm rozbity jest na wiele ujęć interpretowanych pod tym pojęciem. Można określić jednak jego ramy znaczeniowe: „To, co łączy te ujęcia, to założenie, że o wiedzy nie przesądza (a w każdym razie nie całkowicie) świat, będący przedmiotem poznania, ale kształtujący to poznanie współczynnik humanistyczny (...) czy interpretacja humanistyczna" [Klus-Stańska 2010, s. 263]. Pojęcie konstruktywizmu oprzeć można na dwóch jego filarach - neurobiologicznej teorii funkcjonowania mózgu [Spitzer 2011, Springer 2004, Cieszyńska 2013] i jej pedagogicznych implikacjach [Bobryk 1996, Olsen 1996, Gołębniak 2007, Dylak 2000, Gruszczyk-Kolczyńska 1994]. Dotykając zagadnienia podstaw neurobiologicznych konstruktywiz$\mathrm{mu}$, odnieść należy się do badań przeprowadzonych w tej materii. Weryfikacja niektórych tez płynących z analizy badań neurobiologicznych znacząco wpływa na rozumienie koncepcji konstruktywistycznej. Jedna z tez neurobiologicznych dotyczy strukturalnego funkcjonowania mózgu: „są pewne dowody na to, że hipocampus może być istotnie zaangażowany $w$ dynamiczny proces indeksowania nowo zasymilowanych danych oraz $w$ łączenie nowych i istniejących informacji w kontekstowo odpowiednie grupy podczas procesu konstruowania" [Anderson 1997, s. 77]. W efekcie takich doniesień na temat pracy mózgu wywnioskować można, iż wiedza konstruowana w umyśle jest, swego rodzaju, siecią połączeń neuronalnych. Należy również zwrócić uwagę na wyłaniające się z tezy zjawisko rekonstrukcji. Rekonstrukcja polega na zrekonstruowaniu nieaktualnych, błędnych struktur wiedzy w celu lepszej asymilacji i akomodacji nowych informacji. Takie strategie działania umysłu ukazują uczenie się jako ciągły proces polegający na przetwarzaniu, klasyfikacji, interpretacji nowych informacji. Niezbędna do budowania nowych połączeń neuronalnych jest aktywność uczącego się, a więc jego bezpośrednie zaangażowanie $\mathrm{w}$ sam proces uczenia się.

Podejście konstruktywistyczne w dydaktyce i edukacji jest wynikiem analizy i wykorzystania badań psychologicznych i pedagogicznych J. Piageta oraz kontynuatorów jego pracy i teorii poznawczych [Elkind 1967; Bruner 1978; Filipiak 2011]. Aby zrozumieć i poznać koncepcję Piageta, warto sięgnąć do współczesnych publikacji Catherine Twomey Fosnot, która analizuje badania i teorie Piageta, również przez pryzmat najnowszej wiedzy psychologicznej i neurobiologicznej. Cytując Fosnot, wyróżnić można najogólniejszą implikację konstruktywizmu dla dydaktyki: „Zamiast patrzeć na uczenie się jako proces liniowy, należy rozumieć je jako proces kompleksowy i zasadniczo nieliniowy" [Fosnot 1996, s. 10]. Podejście konstruktywistyczne, co najbardziej znaczące dla metody Numicon, jest podstawą współczesnego nauczania matematyki. „Kluczową (...) tezą jest niemożność 
przekazania wiedzy matematycznej poprzez najlepsze nawet pokazy i słowne objaśnienia" [Semadeni 2016, s. 5]. Jeżeli dziecko osiągnęło nawet odpowiedni poziom rozwoju umysłowego i rozumie wszystkie słowa i frazy użyte przez dorosłego, nie gwarantuje to zrozumienia zagadnienia. Zadaniem nauczyciela jest odejście od takiego modelu nauczania. „Nauczyciel powinien organizować rozmaite sytuacje dydaktyczne i stwarzać w ten sposób warunki sprzyjające konstruowaniu się w umysłach uczniów ważnych pojęć i schematów logiczno-matematycznych, które staną się fundamentem ich wiedzy" [Semadeni 2015, s. 14].

W kontekście prowadzonych rozważań warto jeszcze raz podkreślić, że system Numicon jest metodą wyrastającą z konstruktywizmu. Zauważyć można zarówno bezpośrednie odniesienia teoretyczne do niego, jak i zaczerpnięte zeń rozwiązania praktyczne.

\section{Metoda Numicon w badaniach ewaluacyjnych w Wielkiej Brytanii}

Ze względu na szeroką skalę stosowania metoda ta od 1997 roku poddawana jest szeregowi badań ewaluacyjnych. Wszystkie dostępne są na oficjalnej witrynie internetowej Oxford University Press, w dziale poświęconym metodzie Numicon. Chronologiczny wykaz wszystkich badań ilustruje tabela 1. Większość z nich przeprowadzona została na terenie Anglii, a także Walii i Irlandii.

Pierwsze badania nad skutecznością i efektywnością metody opracowane i przeprowadzone zostały przez zespół badaczy, w którego skład weszli: Romey Tacon, Ruth Atkinson (nauczyciele z Peacehaven Infant School) oraz doktor Tony Wing z Uniwesytetu Brighton [Tacon, Atkinson, Wing, 2004]. W raporcie z badań szkoła podpisana jest jako Highhill Infant School, lecz autorzy raportu zastrzegli, iż na jego potrzeby zmieniono nazwę szkoły. Dzieci, w wieku od 4 do 7 lat, podzielone zostały na trzy grupy. Pierwsza grupa realizowała podstawę programową $\mathrm{w}$ ramach dotychczasowej strategii nauczania, a dwie pozostałe pracowały z systemem multisensorycznym. Na przestrzeni dwu lat (1997-1999) ukształtowała się znacząca różnica między grupą pierwszą, a dwoma pozostałymi. Szczególnie wyraźne różnice zanotowano w przypadku poziomu trzeciego baterii diagnostycznej Key Stage 1 SAT's, według którego oceniane były postępy uczniów. Na tym poziomie znalazło się około $50 \%$ uczniów z grup prowadzonych metodą Numicon, natomiast zaledwie $30 \%$ z grupy pierwszej (zob. wykres 1 ). 
Tabela 1. Wykaz badań ewaluacyjnch metody Numicon przeprowadzonych na terenie Wielkiej Brytanii

\begin{tabular}{|c|l|l|l|l|}
\hline Lp. & \multicolumn{1}{|c|}{ Data } & \multicolumn{1}{|c|}{ Szkoła / uczeń } & \multicolumn{1}{|c|}{ Miejscowość } & \multicolumn{1}{|c|}{ Liczba badanych } \\
\hline 1 & $1996-1998$ & Peacehaven Infant School & Peacehaven & 168 uczniów \\
\hline 2 & $2001-2003$ & Hoddern Junior School & Peacehaven & 163 uczniów \\
\hline 3 & $2001-2002$ & - & Wiltshire & 11 uczniów \\
\hline 4 & $2002-2003$ & Richard Leonard & Satmullen & 1 uczeń \\
\hline 5 & $2003-2004$ & - & Portsmouth & 12 uczniów \\
\hline 6 & $2003-2004$ & Sam Uttley & Bradford & 1 uczeń \\
\hline 8 & 2005 & - & Leeds & 23 uczniów \\
\hline 9 & $2006-2007$ & - & Cambridge & 8 szkół \\
\hline 10 & $2006-2008$ & - & Doncaster & 6 szkół \\
\hline 11 & 2010 & Glyncollen Primary School & Swansea & 238 uczniów \\
\hline 12 & 2010 & Francis Askew Primary School & Hull & 271 uczniów \\
\hline 13 & 2010 & - & Southhampton & 1 uczeń \\
\hline 14 & 2011 & - & - & 150 nauczycieli \\
\hline 15 & 2011 & Canon Evans C of E Infant School & Bedworth & 257 uczniów \\
\hline 16 & 2012 & Queen's Park Academy & Bedford & 498 uczniów \\
\hline 17 & 2012 & SS Aidan\&Oswald RC Primary School & Royton & 406 uczniów \\
\hline 18 & 2013 & Nothern Parade Junior School & Portsmouth & 300 uczniów \\
\hline 19 & 2013 & Goodyers End Primary School & Bedworth & 350 uczniów \\
\hline 20 & 2014 & St Joseph's RC Primary School & London & 213 uczniów \\
\hline 21 & 2014 & Newlands Special School & Rochdale & 82 uczniów \\
\hline
\end{tabular}

Źródło: Opracowanie własne na podstawie raportów z badań opublikowanych na stronie: https://global. oup.com/education/content/primary/casestudies/pages/numicon_case_studies?region=international.

Obserwacje nauczycieli $w$ grupach pracujących systemem multisensorycznym, na które zwracają uwagę autorzy raportu, to:

- rozwój pewności siebie i pozytywnego stosunku do matematyki;

- częstsze okazje do operacji na większych zbiorach liczbowych, rozwijające umiejętności matematyczne;

- opieranie operacji umysłowych na reprezentacjach wizualnych;

- poprzedzenie zapisu działań arytmetycznych wieloma ćwiczeniami z użyciem dodawania i odejmowania w działaniu;

- opanowanie przez dzieci umiejętności dodawania i odejmowania z użyciem kształtów przed wprowadzeniem zapisu graficznego działań; 
- rozszerzanie języka matematycznego u dzieci o pojęcia takie jak: pozycja, wzór, kształt, więcej, mniej, większy, mniejszy, parzysty, nieparzysty na podstawie działań na kształtach;

- wykorzystywanie przez dzieci nabytych umiejętności matematycznych również poza szkołą.

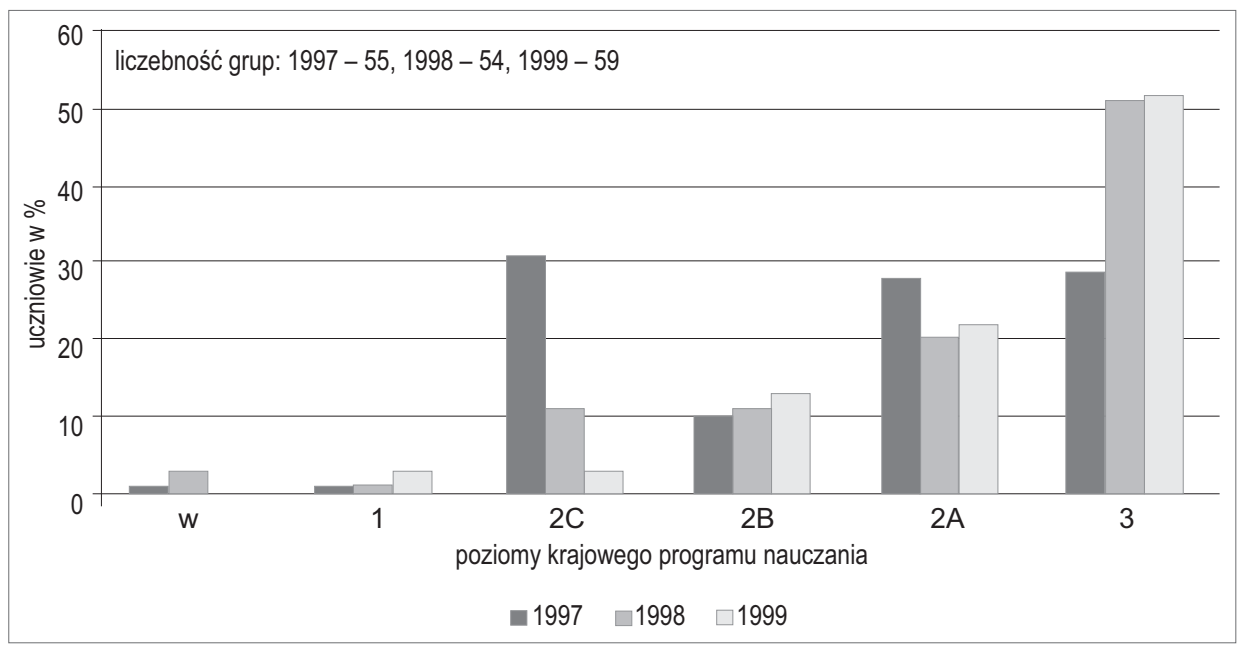

Wykres 1. Wyniki badań przeprowadzonych w Peacehaven Infant School

Źródło: R. Tacon, R. Atkinson, T. Wing, Learning about numbers with patterns, „BEAM”, 2004, nr 4, s. 3.

Analogiczny do poprzedniego projekt przeprowadzony został w latach 2001 2003 w Hoddern Junior School. Zmiana placówki podyktowana była zmianą przedziału wiekowego grupy badanych. Tak więc programem objęte zostały starsze, ośmioletnie dzieci. Znaczący dla zwolenników Numiconu był wynik na piątym poziomie baterii Key Stage 2 SATs: grupa uczniów pracująca systemem Numicon wynosiła 30\%, a grupa prowadzona tradycyjnymi metodami mniej niż 10\% (zob. wykres 2).

Wynik ten był potwierdzeniem hipotezy postawionej przez Atkinson i Tacon. Umiejętności arytmetyczne silnie osadzone w polisensorycznym wyobrażeniu liczby, wychodzące poza strategię przeliczania, przyczyniły się do osiągania przez dzieci wyższych wyników w Key Stage 2 SATs. Projekty te były nie tylko przyczynkiem do powstania metody, ale także do dalszych badań nad jej skutecznością. Badania takie przeprowadziły władze lokalne w Leeds [2005] oraz Doncaster [2008], które zastosowały Numicon jako nowatorską strategię nauczania matematyki dla dzieci, które nie osiągały sukcesów, pracując ze strategiami nauczania typowymi dla programu interwencyjnego Wave 3. 


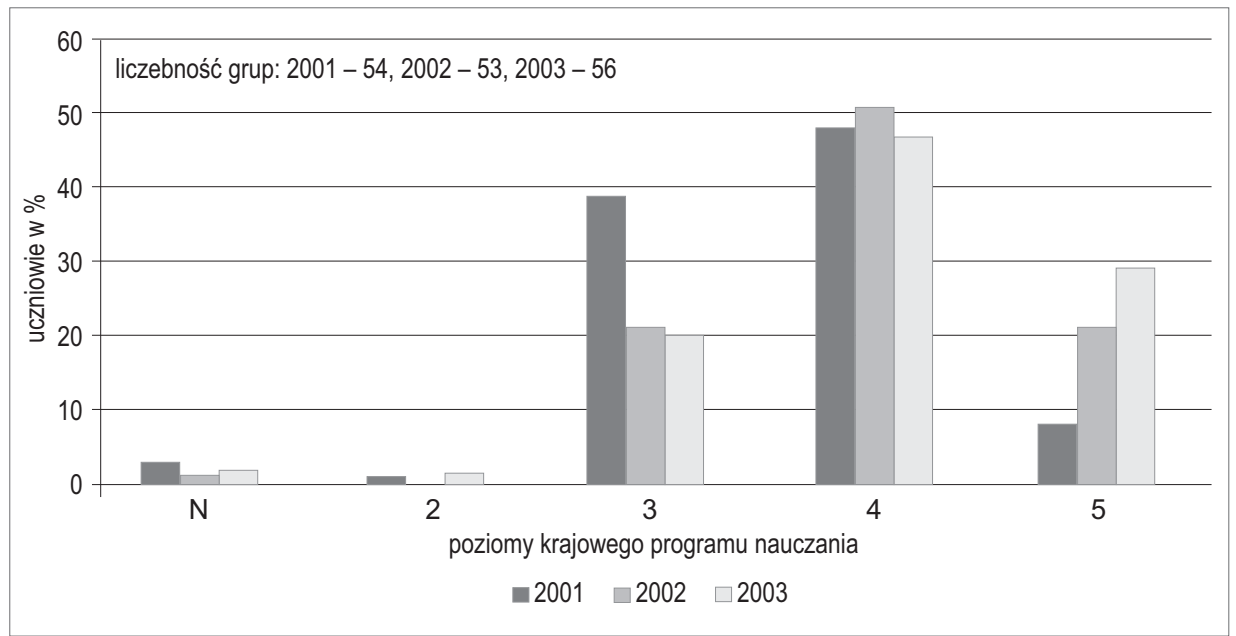

Wykres 2. Wyniki badań przeprowadzonych w Hoddern Junior School

Źródło: R. Tacon, R. Atkinson, T. Wing, Learning about numbers with patterns, „BEAM”, 2004, nr 4, s. 8.

Po pierwszych doniesieniach na temat efektywności metody Numicon systemem zainteresowali się również nauczyciele pracujący z uczniami o specjalnych potrzebach edukacyjnych. Owocem tego zainteresowania był projekt badawczy przeprowadzony w Wiltshire dedykowany dzieciom z Zespołem Downa w wieku 10-12 lat. Grupa badawcza składała się z jedenaściorga dzieci z Zespołem Downa na poziomie Key Stage 2 i 3. Były to dzieci uczęszczające do różnych placówek edukacyjnych: siedmioro z nich do szkoły ogólnodostępnej, dwoje do specjalnego centrum przy szkole ogólnodostępnej oraz dwoje do szkoły specjalnej. Uczniowie pracowali od 10 do 15 minut dziennie z kształtami Numicon. Nauczyciele biorący udział w projekcie odbyli trening z doktorem Tony'm Wing, Romey Tacon oraz Ruth Atkinson i otrzymali od nich gotowe materiały. Narzędziem diagnostycznym była skala British Ability Scales II (BAS II), a ponowny pomiar umiejętności matematycznych przeprowadzono po 4 miesiącach pracy z systemem Numicon. Autorki raportu Claire Iwan i Caroline Mair zwróciły uwagę na kilka aspektów [Ewan, Mair 2002]:

- dzieci bardzo szybko rozróżniały kształty i przyswoiły nazewnictwo używane podczas pracy z systemem;

- niektórzy uczniowie mieli problem z odejściem od wcześniejszych strategii arytmetycznych i zastąpienia ich kształtami Numicon;

- uczniowie częściej osiągali sukcesy w stawianych przed nimi zadaniach matematycznych, kiedy mieli dostęp do kształtów Numicon; 
- dla uczniów, którzy mieli problemy z użyciem pojęć „mniejszy” oraz „większy” (treści te często pomijane są na tym etapie edukacji), dobrą okazją do takich ćwiczeń okazało się użycie w pracy kształtów;

- uczniowie chętnie używali kształtów i podejmowali się zadań matematycznych;

- uczniowie opanowali umiejętności, które wcześniej były dla nich nieosiągalne.

Wyniki testu diagnostycznego wykonanego po 4 miesiącach pracy z kształtami, a więc w lipcu 2001 roku ilustruje zestawienie tabelaryczne (zob. tab. 2).

Tabela 2. Wyniki badań z projektu badawczego przeprowadzonego w Wiltshire

\begin{tabular}{|c|c|c|c|c|}
\hline Uczeń & BAS Słownictwo & $\begin{array}{c}\text { BAS Liczby } \\
\text { (luty 2001) }\end{array}$ & $\begin{array}{c}\text { BAS Liczby } \\
\text { (lipiec 2001) }\end{array}$ & $\begin{array}{c}\text { Postęp } \\
\text { (wiesiącach) }\end{array}$ \\
\hline 1 & 3,5 & 4,6 & 5,4 & $+10 \mathrm{~m}$ \\
\hline 2 & 6,4 & 6,5 & 7,1 & $+8 \mathrm{~m}$ \\
\hline 3 & 4,6 & 6,2 & $6,4(7,1)^{*}$ & $+12 \mathrm{~m}$ \\
\hline 4 & 4,6 & 6,6 & 7,6 & $+3 \mathrm{~m})^{*}(+8 \mathrm{~m})^{*}$ \\
\hline 5 & 6,4 & 5,1 & $5,4(5,9)^{*}$ & $+6 \mathrm{~m}$ \\
\hline 6 & 3,1 & 3,9 & 4,3 & $+11 \mathrm{~m}$ \\
\hline 7 & 6,4 & 4,6 & 5,5 & $+5 \mathrm{~m}$ \\
\hline 8 & 3,1 & 3,1 & 3,6 & $+4 \mathrm{~m}$ \\
\hline 9 & 4,4 & 4,6 & 4,10 & $+1 \mathrm{~m}$ \\
\hline 10 & 3,5 & 4,8 & 4,9 & $0 \mathrm{~m}$ \\
\hline 11 & 3,5 & 3,7 & 3,7 & +2 \\
\hline
\end{tabular}

*Liczby w nawiasach przedstawiają wyniki właściwe dla wieku, kiedy uczniowie mogli wykorzystać do rozwiązania zadania materiały Numiocon.

Źródło: C. Ewan, C. Mair, Wiltshire Pilot Project - Numicon (March-July 2001), „Down Syndrome News and Update", 2002, nr 2, s. 14.

Zaskakujące są wyniki uczniów, którzy w ciągu czteromiesięcznej pracy, trwającej zaledwie 10-15 minut dziennie, uzyskali wyniki o ponad 10 miesięcy większe niż przy pierwszym pomiarze. Progres większy niż czas trwania projektu osiągnęło w sumie sześcioro uczniów z jedenastoosobowej grupy. Ponadto w przypadku dwóch uczniów stwierdzono ogromne różnice podczas drugiego pomiaru, w zależności od tego, czy uczeń w zadaniu mógł skorzystać z kształtów Numicon, czy musiał wykonać zadanie bez nich. Uczniowie osiągali zdecydowanie wyższe wyniki, kiedy rozwiązywali zadanie z użyciem klocków. Różnice te wynoszą odpowiednio 5 i 9 miesięcy. Autorki podkreślają, że wyniki projektu badawczego są bardzo zróżnicowane, ale ukazują, jak wielki potencjał tkwi w wykorzystaniu metody Numicon w pracy z dziećmi z Zespołem Downa [Ewan, Mair 2002]. 
W literaturze badawczej oprócz tak obszernych projektów znalazły się również projekty mniejsze, realizowane $\mathrm{w}$ formie studium przypadku. Jednym $\mathrm{z}$ nich jest publikacja nauczycielki szkoły specjalnej Kerrie Coleman, która dzieli się swoim doświadczeniem i spostrzeżeniami na temat pracy metodą Numicon ze swoim podopiecznym, czternastoletnim Richardem Leonardem z Zespołem Downa [Coleman 2003]. Nauczycielka została zainspirowana do wdrożenia systemu Numicon w swojej codziennej pracy przez rodzica jednego z podopiecznych. Wzięła również udział w szkoleniu organizowanym przez Down Syndrome Ireland i prowadzonym przez Vikki Horner. Pracę z systemem rozpoczęli wraz z Richardem we wrześniu 2002 roku. Spotkania odbywały się w godzinach porannych z Grainne Finglas, będącą Special Needs Assistant Richarda, pod okiem Kerrie Coleman. Na początku odbywały się one w tym samym pomieszczeniu, w którym prowadzone były lekcje z pozostałą częścią klasy, potem przeniesiono je do osobnego pomieszczenia ze względu na problemy z koncentracją Richarda. Nauczycielki ogromny nacisk położyły na wyznaczenie tygodniowych, ściśle określonych celów oraz systematyczność i rutynowość zajęć. Prowadziły także wraz z Richardem dziennik jego aktywności, podkreślając sukcesy i trudności. Po miesiącu pracy w szkole Richard zaczął pracować również w domu z systemem Numicon. W grudniu 2002 roku pracował już na siódmym etapie systemowego nauczania metodą Numicon. Wykonywał zadania wymagające dodawania i odejmowania przy użyciu kształtów Numicon, także je zapisując. W tym czasie poprawiła się motywacja ucznia do ćwiczeń oraz poziom jego samooceny, a także zdolność podążania za instrukcją oraz koncentracja. Nauczycielki po sukcesie Richarda wprowadziły system do pracy z pozostałymi uczniami.

Jednym z najważniejszych projektów ewaluacyjnych były trwające rok badania przeprowadzone w Portsmouth przez organizację The Down Syndrome Educational Trust. Założenia, sposób przeprowadzenia badań, wyniki i ich analizę przedstawiają w swoim artykule dla "Down Syndrome News and Update" dr Joanna Nye, Sue Buckley oraz Gillian Bird [Bird, Nye, Buckley 2005]. Do projektu włączono grupę szesnaściorga uczniów z zespołem Downa w przedziale wiekowym 5-14 lat, uczęszczających głównie do szkół ogólnodostępnych. Była to „the Numicon group", a więc grupa uczniów, którzy podczas trwania projektu pracować mieli metodą Numicon. Pięcioro z nich pracowało wcześniej z systemem Numicon. Grupą kontrolną byli uczniowie z zespołem Downa uczęszczający do 24 lokalnych, ogólnodostępnych szkól, wśród których rozwój umiejętności matematycznych badała Angela Byrne, również z The Down Syndrome Educational Trust, w latach 1994-1998. Podstawą kształtowania grup porównawczych były podobne profile rozwojowe wszystkich uczniów. Na początku 2003 roku poziom umiejętności matematycznych i językowych uczniów oceniono za pomocą wystandaryzowanych testów, których struktura i zawartość odpowiadała testom 
wykorzystanym w grupie kontrolnej. Testy to między innymi: Basic Number Skills, Word Reading, Recall of Digits będące podtestami British Ability Scales (BAS) oraz The British Picture Vocabulary Scale (BPVS) oraz The Test of Reception of Grammar (TROG). Określanie poziomu językowego uczniów miało na celu zapewnienie odpowiedniego doboru uczniów do grup projektowych. Poza diagnozą testową prowadzona była regularna obserwacja zajęć. Ponadto nauczyciele prowadzili codzienne rejestry odbytych zajęć, które również znalazły się w dokumentacji projektu. Podstawowe warsztaty przygotowujące nauczycieli oraz rodziców do pracy z systemem przeprowadzili dwukrotnie w styczniu oraz we wrześniu dr Joanna Nye oraz zewnętrzny konsultant metody. Dzięki warsztatom ujednolicono schemat pracy podczas trwania projektu. Przyjęto pracę z systemem Numicon $w$ wymiarze 10-15 minut dziennie, rozpoczynając od poziomu Foundation, również $\mathrm{w}$ przypadku dzieci, które wcześniej pracowały z systemem. Autorzy zastrzegają jednak, że w trakcie projektu dostosowywano czas oraz sposób realizacji zajęć do indywidualnych potrzeb dziecka. Wnioski z badań formułowano na podstawie zarówno ilościowych, jak i jakościowych danych projektowych. Z analizy danych wyłączono wyniki uczniów, którzy w ramach baterii diagnostycznej BAS uzyskały zero punktów. W rezultacie analizie poddano wyniki 12 uczniów z grupy eksperymentalnej oraz 18 uczniów z grupy kontrolnej. Wyniki badań ilościowych prezentuje tabela 3 .

Tabela 3. Dane ilościowe uzyskane w ramach badań projektu przeprowadzonego w Portsmouth

\begin{tabular}{|l|c|c|c|}
\hline & Pomiar 1 & Pomiar 2 & $\begin{array}{c}\text { Różnica } \\
\text { między pomiarami }\end{array}$ \\
\hline Grupa kontrolna & $50,33(41-64)$ & $55,33(44-80)$ & $5,00(-1-16)$ \\
\hline Grupa Numicon & $49,17(38-74)$ & $55,00(38-74)$ & $5,83(-2-14)$ \\
\hline
\end{tabular}

Źródło: J. Nye, S. Buckley, G. Bird, Evaluating the Numicon system as a tool for teaching number skills to children with Down syndrome, "Down Syndrome News and Update” 2002, nr 5, s. 5.

Uśredniając różnicę $w$ wynikach obu grup, grupa eksperymentalna osiągnęła o 17\% wyższe wyniki niż grupa kontrolna. Autorzy podkreślają ograniczenia, jakie wynikają ze specyfiki pomiarów ilościowych, m.in. towarzyszące uczniom inne trudności takie jak: ubytki słuchu, zaburzenia zachowania, dwujęzyczność oraz inne czynniki, np. kreatywność nauczyciela czy zaangażowanie ucznia. Świadomość tych ograniczeń była podstawą do rozszerzenia projektu o dane jakościowe. W rezultacie wyróżniono 23 pozytywne aspekty metody oraz 10 trudności, na jakie natrafiono podczas pracy z systemem. Pozytywy, na jakie zwrócono uwagę (zob. tabela 4), skategoryzowano według niektórych obszarów 
edukacji matematycznej (m.in. liczenie i rozumienie podstawowych liczb, rozumienie wartości pieniędzy) oraz możliwości dydaktycznych, jakie daje metoda.

Tabela 4. Dane jakościowe (zalety metody) uzyskane w ramach badań projektu przeprowadzonego w Portsmouth

\begin{tabular}{|c|c|}
\hline Obszar analizy & Obserwacje nauczycieli \\
\hline $\begin{array}{l}\text { Przeliczanie } \\
\text { i rozumienie podsta- } \\
\text { wowych liczb }\end{array}$ & $\begin{array}{l}\text { - Numicon pozwala wyjaśniać pojęcia związane z liczbami; } \\
\text { - używając kształtów można łatwo/przejrzyście zaprezentować różnice } \\
\text { pomiędzy liczbami z końcówką „-teen” oraz „-ty” („,-naście” oraz } \\
\text { "'-dziesiąt”, które często są mylone przez dzieci, prawdopodobnie } \\
\text { przez podobne brzmienie); } \\
\text { - } \text { sekwencje liczbowe mogą zostać wydłużone (np. dzieci, które na } \\
\text { początku pracy potrafily liczyć w zakresie 10, teraz potrafią liczyć } \\
\text { w zakresie 100); } \\
\text { - rozumienie wartości liczb w zakresie } 10 .\end{array}$ \\
\hline $\begin{array}{l}\text { Przejrzystość kroków } \\
\text { matematycznych }\end{array}$ & $\begin{array}{l}\text { - liczby parzyste i nieparzyste są bardzo przejrzyście przedstawione } \\
\text { w kształtach Numicon, co sprzyja rozumieniu przez dzieci tych pojęć; } \\
\text { - dodawanie jest bardzo dobrze przedstawione wizualnie poprzez } \\
\text { łączenie kształtów (rozwiązanie jest widoczne natychmiast bez liczenia, } \\
\text { kiedy kształty są znane dziecku); } \\
\text { - relacje międzyliczbowe są przejrzyście zaprezentowane, a ich nauka } \\
\text { jest łatwiejsza z użyciem kształtów; } \\
\text { - liczby podwojone są dobrze przedstawione pod kątem wizualizacyjnym. }\end{array}$ \\
\hline Pieniądze & $\begin{array}{l}\text { - znacząco pomaga w odkrywaniu wartości poszczególnych monet, } \\
\text { dopasowywanie ich do kształtów Numicon. }\end{array}$ \\
\hline $\begin{array}{l}\text { Znaczenie wizualnych } \\
\text { i multisensorycznych } \\
\text { aspektów metody }\end{array}$ & $\begin{array}{l}\text { - wizualne aspekty systemu są bardzo praktyczne i przynoszą widoczne } \\
\text { efekty wśród uczniów; } \\
\text { - możliwość „poczucia” kształtów jest taktylnym wymiarem multisenso- } \\
\text { ryczności systemu; } \\
\text { - kształty są atrakcyjne i interesujące dla dzieci. }\end{array}$ \\
\hline $\begin{array}{l}\text { Atrakcyjność } \\
\text { materiału }\end{array}$ & $\begin{array}{l}\text { - materiały są bardzo interesujące dla dzieci, które spontanicznie chcą } \\
\text { brać udział w aktywnościach i eksplorowaniu kształtów; dzieci czerpią } \\
\text { z tego radość; praca z kształtami jest dla uczniów formą zabawy. }\end{array}$ \\
\hline $\begin{array}{l}\text { Adaptacyjność } \\
\text { metody }\end{array}$ & $\begin{array}{l}\text { - możliwe jest dostosowanie aktywności do indywidualnych potrzeb } \\
\text { podczas pracy z grupą. }\end{array}$ \\
\hline Postęp dziecka & $\begin{array}{l}\text { - można dokładnie dostrzec progres, jakiego dziecko dokonało; } \\
\text { - brak potrzeby zapisywania wyniku. }\end{array}$ \\
\hline $\begin{array}{l}\text { Przydatność w pracy } \\
\text { z innymi dziećmi }\end{array}$ & $\begin{array}{l}\text { - dowiedziona użyteczność wśród innych dzieci z opóźnieniami w zakre- } \\
\text { sie matematyki (np. ze specjalnymi potrzebami edukacyjnymi). }\end{array}$ \\
\hline Planowanie nauczania & $\begin{array}{l}\text { struktura aktywności bardzo użyteczna dla asystenta nauczyciela w plano- } \\
\text { waniu aktywności i przewidywaniu następnych kroków -pozwala na opra- } \\
\text { cowanie całych lekcji ukierunkowanych na kształtowanie poszczególnych } \\
\text { umiejętności matematycznych, które są wyszczególnione w karcie i praco- } \\
\text { wać na niej w tempie ucznia (częściej niż w tempie klasy). }\end{array}$ \\
\hline
\end{tabular}




\begin{tabular}{|c|l|}
\hline Obszar analizy & \multicolumn{1}{c|}{ Obserwacje nauczycieli } \\
\hline \multirow{5}{*}{ Inne umiejętności } & - poprawa umiejętności zamiany ról (zamiana ról wykorzystywana jest \\
& w wielu zadaniach) oraz poprawa umiejętności słuchania innych \\
& (konieczność słuchania, by dowiedzieć się, co trzeba zrobić w swojej \\
& części zadania); \\
& - rozwój samodzielności; \\
& - poprawa sprawności motoryki małej u niektórych uczniów poprzez \\
& manipulację kształtami; \\
& - wzrost pewności siebie; \\
& - rozwój innych umiejętności poznawczych, np. umiejętność rozpozna- \\
wania i nazywania kolorów.
\end{tabular}

Źródło: J. Nye, S. Buckley, G. Bird, Evaluating the Numicon system as a tool for teaching number skills to children with Down syndrome, „Down Syndrome News and Update” 2002, nr 5, s. 7.

\section{Trudności, jakie napotkali nauczyciele podczas pracy przedstawia tabela 5 .}

Tabela 5. Dane jakościowe (ograniczenia metody) uzyskane w ramach badań projektu przeprowadzonego w Portsmouth

\begin{tabular}{|c|c|}
\hline Obszar analizy & Obserwacje nauczycieli \\
\hline Materiały systemowe & $\begin{array}{l}\text { - kroki w zadaniach są zbyt duże - każde ćwiczenie wymaga rozłożenia } \\
\text { na więcej kroków; } \\
\text { - niektórzy uczniowie zbytnio koncentrowali się na łączeniu kształtów } \\
\text { z kołkami; } \\
\text { - } \text { worek z zestawu dla niektórych uczniów był nieatrakcyjny i trudny do } \\
\text { wykorzystania, a użycie modeliny/plasteliny nie było przez nich akcep- } \\
\text { towane (podstawowe ćwiczenie 18, które wymaga ich użycia, było dla } \\
\text { nich trudne do wykonania); } \\
\text { - uczniowie z trudnościami w zakresie motoryki małej unikali użycia } \\
\text { kołków i wykonywali zadania tylko z użyciem kształtów; } \\
\text { - różnica między kolorystyką kształtów Numicon oraz pasków utrudnia } \\
\text { dzieciom pracę z systemem. }\end{array}$ \\
\hline $\begin{array}{l}\text { Praca z systemem } \\
\text { Numicon }\end{array}$ & $\begin{array}{l}\text { - włączenie systemu w pracę całej szkoły może być bardzo użyteczne, } \\
\text { ale trudne, ponieważ Numicon jest postrzegany przez uczniów jako } \\
\text { zadania dla „dzieci z Zespołem Downa”; } \\
\text { - trudnością jest rozbieżność między zadaniami z systemu Numicon } \\
\text { a zadaniami w klasie (ogólnodostępnej); } \\
\text { - praca z niektórymi uczniami systemem Numicon na lekcjach może roz- } \\
\text { praszać innych uczniów; } \\
\text { - nie pojawił się oczekiwany transfer umiejętności zdobytych w ramach } \\
\text { pracy systemem Numicon do rozwiązywania innych zadań. }\end{array}$ \\
\hline Projekt badawczy & $\begin{array}{l}\text { - rejestrowanie wyników (w ramach projektu badawczego) trudno sfor- } \\
\text { mułować tak, aby były zrozumiałe dla wszystkich. }\end{array}$ \\
\hline
\end{tabular}

Źródło: J. Nye, S. Buckley, G. Bird, Evaluating the Numicon system as a tool for teaching number skills to children with Down syndrome, „Down Syndrome News and Update” 2002, nr 5, s. 9. 
Można zauważyć, że większość z wyżej wymienionych trudności wynika ze stylu pracy nauczyciela oraz niedostosowania systemu do pracy z uczniami z Zespołem Downa (na przykład nieuwzględnianie trudności motorycznych, trudności w zapamiętywaniu różnej kolorystyki materiałów czy wykonywaniu zadań w całości, bez rozłożenia ich na mniejsze etapy). Całość projektu jest jednym z najobszerniejszych źródeł dotyczących pracy z systemem Numicon z uczniami z niepełnosprawnością intelektualną.

Kolejnym źródłem doniesień na temat skuteczności metody Numicon był projekt badawczy przeprowadzony na terenie hrabstwa Cambridge. System został wykorzystany w ramach programu interwencyjnego Wave 3 (zob. wykres 3).

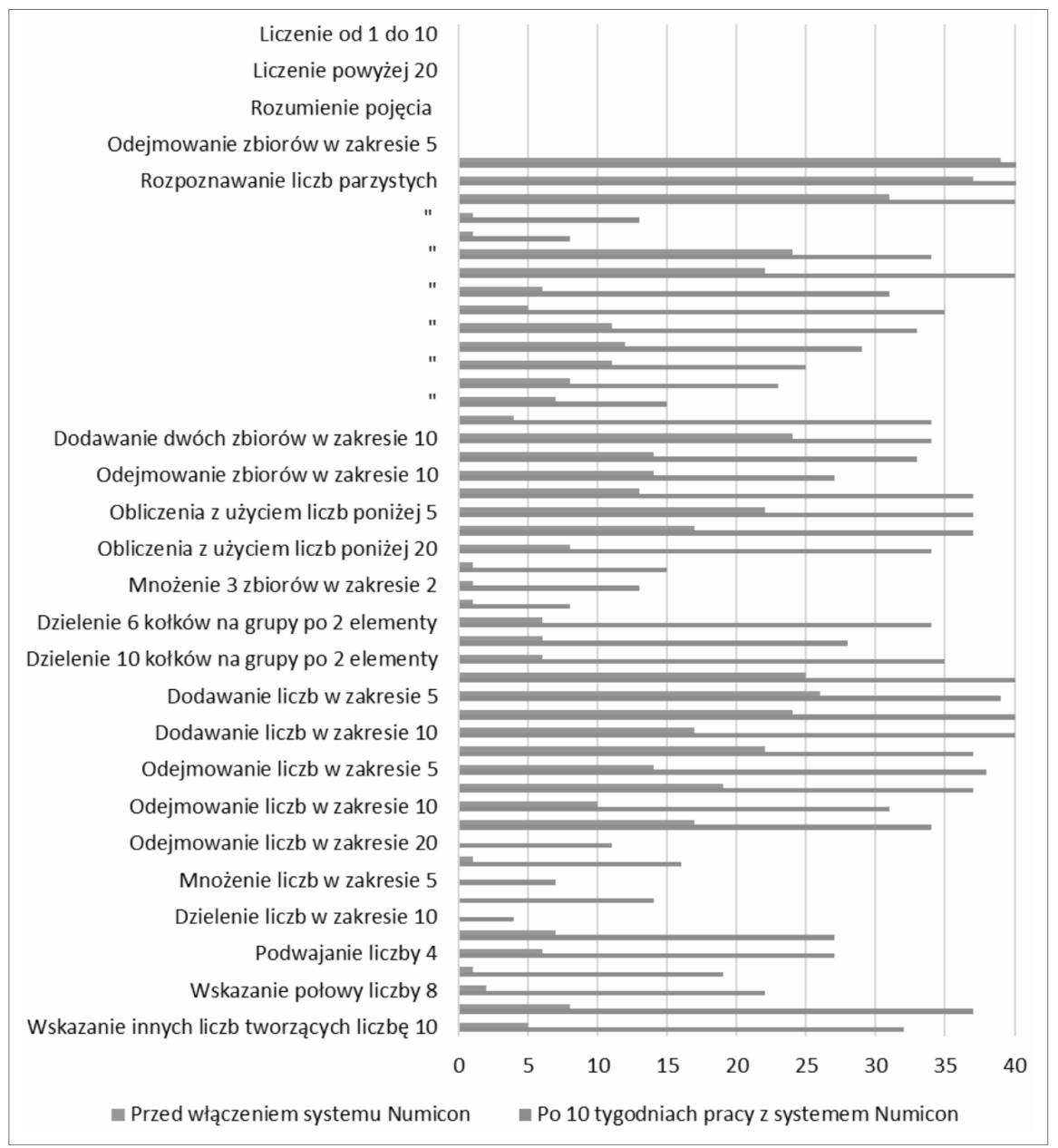

Wykres 3. Wyniki badań projektu ewaluacyjnego przeprowadzonego na terenie Cambridge Źródło: http://lib.oup.com.au/primary/numicon/research/Gathering-Evidence-15498.pdf [dostęp: 15.04.2017]. 
Zajęcia metodą Numicon odbywały się dwu- lub trzykrotnie w ciągu tygodnia i trwały 25 minut. W raporcie grupa uczniów objętych programem nie została ściśle określona, ale z zestawienia wywnioskować można, że liczyła ona około czterdziestu uczniów. Wyszczególniono 48 umiejętności matematycznych, które podlegały badaniu diagnostycznemu. W przypadku podstawowych umiejętności, takich jak liczenie w zakresie 20, nie odnotowano znaczących różnic między początkową fazą projektu a jego końcem. Kolejne, bardziej skomplikowane umiejętności matematyczne, to m.in. identyfikacja numerów parzystych i nieparzystych, rozumienie zasady większy/mniejszy o jeden/dwa/dziesięć, dodawanie, odejmowanie, mnożenie/dzielenie, podawanie wielokrotności liczb 5 oraz 4, podawanie połowy liczb 6 i 8, odszukiwanie dwóch liczb tworzących liczbę 10 . W przypadku tych umiejętności między pierwszym i drugim pomiarem aż trzydziestu uczniów opanowało daną umiejętność. Biorąc pod uwagę wszystkie umiejętności opisane $\mathrm{w}$ raporcie, podczas trwania projektu każdą umiejętność opanowało średnio szesnastu uczniów. Wynik jest imponujący, szczególnie gdy weźmie się pod uwagę, że niektórych umiejętności nie posiadało żadne dziecko $\mathrm{w}$ grupie (np. mnożenie w zakresie 5 czy dzielenie w zakresie 10), a po pracy z systemem Numicon umiejętności te przejawiało od pięciu do trzynastu uczniów.

Wykorzystywanie systemu Numicon w szkołach brytyjskich podlega ciągłej ewaluacji, co owocuje nowymi propozycjami wydawniczymi i rozwiązaniami praktycznymi. W związku z sukcesem, jaki system odniósł w Wielkiej Brytanii, zaczęto wprowadzać go w szkołach na całym świecie. Kilka lat temu wprowadzono go na rynek polski i analogicznie do doświadczeń brytyjskich podejmowane są próby ewaluacji metody na gruncie polskim.

\section{Metoda Numicon w badaniach polskich}

Pomimo dostępności systemu Numicon w Polsce i wprowadzeniu go do praktyki edukacyjnej $w$ wielu polskich szkołach, niewiele jest materiałów czy publikacji na jego temat. Praktycznym rozwiązaniom wykorzystania systemu Numicon poświęcony jest artykuł autorstwa dr Aleksandry Szulman-Wardal oraz dr. Arkadiusza Mańskiego [Szulman-Wardal, Mański 2014]. W 2017 autorka tego tekstu przeprowadziła badania na gruncie polskim. Ich celem było poznanie doświadczeń nauczycieli polskich w pracy metodą Numicon z uczniami z niepełnosprawnością intelektualną. Problem badawczy projektu został postawiony $\mathrm{w}$ formie pytania: Jakie są doświadczenia nauczycieli w pracy metodą Numicon na etapie przedszkolnym i wczesnoszkolnym w edukacji dzieci niepełnosprawnych intelektualnie? Ze względu na tak zakrojone pole empiryczne wybraną orientacją ba- 
dawczą były badania jakościowe. Dane uzyskano w drodze wywiadów narracyjnych eksperckich $w$ charakterze indywidualnej rozmowy z trzema osobami wykorzystującymi metodę Numicon w swojej pracy. Pierwszą badaną była Pani Beata - logopeda i matematyk, na co dzień pracująca w Ośrodku Szkolno-Wychowawczym dla Niesłyszących i Słabosłyszących jako nauczyciel matematyki oraz prowadząca terapię logopedyczną $w$ ramach wczesnego wspomagania rozwoju w prywatnym gabinecie. W pracy z dziećmi z zaburzeniami rozwoju posiada 25-letnie doświadczenie. Drugą badaną była Pani Iwona, która zaangażowana jest w działania Fundacji Wspierania Rozwoju JA TEŻ, działającej na rzecz wspierania rozwoju dzieci z niepełnosprawnością intelektualną. $Z$ ramienia fundacji uczestniczyła w kursie metodycznym Numicon organizowanym przez Oxford University Press w Londynie. Obecnie prowadzi zajęcia indywidualne z dziećmi niepełnosprawnymi intelektualnie w oparciu o system Numicon. Ostatnim badanym był Pan Arkadiusz, psycholog i dyplomowany logopeda, doktor nauk społecznych, wykładowca akademicki na jednym z polskich uniwersytetów. Przez kilkanaście lat pracował w Specjalnym Ośrodku Szkolno-Wychowawczym. Obecnie prowadzi Pracownię Psychologiczno-Logopedyczną zorientowaną między innymi na wspieranie dzieci z zespołami genetycznymi.

Ze względu na dużą rozbieżność doświadczeń zawodowych badanych metoda omówiona była z wielu perspektyw. Wspólnym punktem wyjścia wszystkich narracji była potrzeba zmiany dotychczasowych strategii nauczania matematyki wśród uczniów z niepełnosprawnością intelektualną. Każdy z badanych dostrzegał niewykorzystany potencjał wśród swoich uczniów i był świadomy potrzeby zmiany metod pracy. Decyzja o podjęciu wyzwania, jakim jest praca nieznaną w Polsce metodą, której poznanie wymaga ogromnego zaangażowania, świadczy o kolejnej, wspólnej cesze badanych - otwartości na samorozwój i gotowości do zmian i działania na rzecz rozwoju swoich podopiecznych. Właśnie takie cechy odpowiadające konstruktywistycznym tendencjom w myśleniu o uczniu i edukacji przyczyniły się do zainteresowania i wprowadzenia w swój warsztat pracy systemu Numicon.

Uzyskany materiał empiryczny pozwolił na wyodrębnienie dwóch głównych obszarów: (1) możliwości, jakie upatrują badani w metodzie Numicon, (2) dostrzegane przez nich ograniczenia wykorzystania systemu Numicon w edukacji osób z niepełnosprawnością intelektualną.

W pierwszym obszarze analizy empirycznej cechą, która we wszystkich wypowiedziach określona została jako największa zaleta klocków Numicon, jest wykorzystana w nim wizualna reprezentacja liczb. W swojej wypowiedzi Pani Beata określa ją następującymi słowami:

W Numiconie przede wszystkim doceniam wizualizację liczby. Przekłada się ona na wszystkie umiejętności matematyczne, których można uczyć dzieci kształtami Numicon. (...) Wczesne 
wprowadzenie systemu wedukacji daje dzieciom możliwość przywołania obrazu liczby w pamięci i usprawnia to liczenie w pamięci.

Pani Iwona w podobny sposób odniosła się do tego elementu systemu:

W systemie urzekło mnie to, w jaki sposób liczby sa przedstawione i to, że system opiera się głównie na percepcji wzrokowej. U naszych dzieci z Zespołem Downa jest to szczególnie istotne. (...) Kiedy dzieci uczą się liczb w takiej postaci, później kiedy klocki znikają, są w stanie przywotać je w swojej pamięci wzrokowej i usprawnia to ich liczenie w pamięci.

Ostatnią wypowiedzią, również odnoszącą się do tego przymiotu metody Numicon, była wypowiedź Pana Arkadiusza:

W systemie Numicon liczba jest reprezentowana w unikalnym połaczeniu trzech cech: koloru, ksztattu i faktury. Na początku doświadczeń edukacyjnych dziecko więc nie liczy, lecz spostrzega ilość. Może więc zapamiętać kolor, ksztatt i powiązać go z symbolem. Istotnie skraca się czas ustalania wartości zbioru. To bardzo ważne, aby «dotknaćlwłaczyć» w dziecku operacje szybsze i w pewnym sensie angażujące najsilniejszy zmyst. System Numicon okazuje się bardziej skuteczny u dzieci o mocnej percepcji wzrokowej.

Warto zwrócić uwagę na podkreślane przez badanych znaczenie wykorzystania kanału wzrokowego właśnie w pracy z dziećmi z niepełnosprawnością intelektualną, które nabywanie nowych umiejętności opierają na percepcji wzrokowej. Poruszenie kwestii graficznej reprezentacji kształtów, charakterystycznej dla systemu Numicon, nasuwa kolejną cechę systemu, a mianowicie stałość materiału i enaktywną reprezentację liczb. Potwierdzenie tego odnaleźć można w wypowiedzi Pani Beaty:

Ważne jest to, że system oparty jest na konkrecie, czyli podstawie rozwoju, a to ma duże znaczenie dla dzieci niepetnosprawnych intelektualnie.

Zalety konsekwencji w użyciu kształtów i co za tym idzie stałości systemu podkreśla w swojej wypowiedzi również Pan Arkadiusz:

W jego konstrukcji widzimy kumulację cech wizualnych i to jest stałe. Statość to pierwsza mocna strona tego narzędzia.

Powiązana z wizualizacyjną stroną systemu Numicon jest kolejna jego aprobowana cecha, a mianowicie przejrzystość reprezentacji działań matematycznych, a także łączenia kształtów. Na tę cechę zwróciła uwagę Pani Beata:

Świetnie przedstawione jest dodawanie i odejmowanie ksztattów, gdzie widać jak pod wptywem działania kształty się zmieniają.

Dzieci mogą nakładać na siebie kształty i dzięki temu łatwiej jest im dostrzec, jakie zmiany w ilości zaszły. Niezwykle istotne jest to również w przypadku dopełniania zbioru do danej liczby, o czym również wspomniała Pani Beata: 
Dobrze ukazanie jest dopetnianie liczby, gdzie widać jak liczba mniejsza dopetnia liczbę większa i odwrotnie. Wcześniej próbowałam uczyć dzieci dopetniania na paluszkach, na liczydłach, ale nie przynosito to zamierzonego efektu. Tutaj, kładac jeden kształt na drugi, dziecko od razu wi$d z i$, ile brakuje.

Sposób zaprojektowania klocków przyczynił się do zmian strategii rozumienia zależności między liczbami przez uczniów, co jest niezwykle istotne przy wykonywaniu nawet podstawowych działań arytmetycznych. Druga z badanych, Pani Iwona, przy okazji rozmowy na temat wizualnych aspektów systemu Numicon zwróciła uwagę na kolejną zaletę takiego rozwiązania:

Dla dzieci, które opanowały już liczby w zakresie dziesięciu ogromnym wyzwaniem jest przekroczenie progu dziesiątki. Często wykonując dziatania na dużych liczbach, nawet w zakresie pięćdziesięciu, zapominają o przekraczaniu kolejnych progów dziesiątkowych. Ten problem mają też dzieci petnosprawne. Ja pracowałam z moja petnosprawna córka na klockach Numicon, właśnie ze względu na jej problemy z działaniami na liczbach większych od dziesięć.

Ze względu na swoje multisensoryczne podłoże kształty Numicon oddziałują nie tylko na wzrok, ale również na zmysł dotyku dziecka. Dzięki konturukcji kształtów i wykorzystanych w nich otworów, których ilość odpowiada reprezentowanej liczbie, dziecko używa naturalnego liczmana, jakim są palce i może sprawdzić dokładną liczebność konkretnego kształtu. Jego taktylny wymiar poruszony został przez wszystkich badanych. Na ten temat wypowiedział się najszerzej Pan Arkadiusz:

Wreszcie chyba najmocniejszym filarem Numicon jest jego rehabilitacyjny potencjat. Przekonatem się o tym osobiście prowadząc trójkę uczniów z tetrapareza spastyczną. Te dzieci nie mogły w żaden sposób nauczyć się matematyki w zakresie podstawowym. (...) Wprowadzenie na ścieżkę edukacyjno-rehabilitacyjna materiatu Numicon spowodowało fundamentalna zmiane (...) Możliwość wzięcia liczby do ręki mocno spastycznej i manipulowania nią, układania na tablicy z wypustkami, gdzie materiał się nie przesuwa, powoduje, że stabilizuje sięi ona w enaktywnej i ikonicznej reprezentacji. Ta grupa dzieci szczególnie potrzebuje doświadczenia dotknięcia czegoś, co ma stać się psychologicznym zasobem dla symboli, które bez tego multisensorycznego fundamentu niewiele znacza. (...).

Otwiera to nową ścieżkę nauczania matematyki dzieci ze sprzężonymi niepełnosprawnościami, a więc intelektualną i ruchową. Pani Iwona zwróciła uwagę na grafomotryczne możliwości wykorzystania kształtów:

Pamiętam, jak prowadziłam zajęcia z chtopcem z Zespołem Downa, który nie lubit rysować, pisać czy kolorować. Nie mogłyśmy z mamą wyjść ze zdumienia, kiedy dzięki klockom Numicon podjąt się zadan grafomotorycznych. Zacząt odrysowywać ksztatty, a także kolorować ich kontury"

Stwierdzenie to przesuwa tak naprawdę obszar oddziaływań z obszaru stymulacji rozwoju matematycznego w inne obszary rozwoju dziecka, takie jak rozwój 
grafomotoryczny, ale także wiąże się bezpośrednio z atrakcyjnością kształtów. Pani Beata bardzo podkreśla to w swojej wypowiedzi:

Małe dzieci, kiedy zaczynają pracę z tymi klockami, sa nimi po prostu zafascynowane. Zawsze bardzo chętnie podejmują się aktywności z użyciem klocków. Można zauważyć, jak kształty rozbudzają wyobraźnię i ciekawość dzieci”. Podobne obserwacje przytacza Pani Iwona: „Dla mnie ważne jest też to, że dzieci bardzo lubią pracę z klockami. Bardzo chętnie przychodzą na zajęcia i chętnie na nich pracuja.

Motywacja ucznia wynikająca z samego narzędzia jest dla nauczyciela bardzo dogodną sytuacją. Postawiony on zostaje przed wyborem dwóch dróg: wykorzystanie motywacji i klocków do tworzenia ciekawych zadań lub wybór systemowego podejścia do metody Numicon, co może zmienić motywację dziecka, która niestymulowana i niewspierana wygaśnie. Dylemat wyboru roli, w jakiej postawi się nauczyciel, mający w ręku takie narzędzie jak system Numicon, kieruje uwagę badacza na kolejny obszar ewaluacji metody. Tym razem jest to obszar dotyczący nauczyciela i jego warsztatu pracy, a nie samego ucznia. Pan Arkadiusz określił to jako elastyczność i otwartość systemu, bezpośrednio powiązane z kreatywnością nauczyciela:

Druga mocna strona tego systemu jest elastyczność i otwartość. Kreatywny nauczyciel może budować bogate w różnorodne fabuly scenariusze lekcji, wykorzystując nie tylko klocki Numicon, ale i pomoce dodatkowe, między innymi suwaki, wagę, zegary, kostki. (...) To dosyć dla mnie niezwykłe, gdyż system Numicon szybko rozróżni nauczycieli kreatywnych i wartościowych od nieelastycznych i mało twórczych, przygniecionych rutyną. To jego kolejna zaleta.

W momencie kiedy nauczyciel znajdzie się w pierwszej grupie opisanej przez Pana Arkadiusza, otwiera się przed nim wachlarz możliwości wykorzystania i modyfikacji systemu w swojej pracy pedagogicznej. Pani Iwona określiła te zależności następującymi słowami:

Klocki Numicon daja nauczycielowi ogromne możliwości. Widzę po sobie i innych terapeutkach, jak wiele zadań i aktywności z klockami można stworzyć. Myślę, że ma tutaj znaczenie kreatywność nauczyciela czy terapeuty. (...) Można z klocków układać sekwencje czy szeregować ksztatty gradualnie, a także dokonywać ich kategoryzacji. Ponad to dzięki klockom można stymulować zarówno pamięć wzrokowa, jak i stuchową. Numiki są też bardzo fajnym materiałem do tworzenia różnych gier edukacyjnych.

Numicon staje się narzędziem do rozwijania możliwości percepcyjnych dzieci, a także mechanizmów myślenia. Wymaga to jednak od nauczyciela kreatywności i dostrzeżenia mnogości możliwości wykorzystania kształtów. Dobrą konkluzję tych zależności sformułował Pan Arkadiusz:

System Numicon w mojej ocenie jest niezwykle interesująca alternatywa dla pedagoga specjalnego. Jednak właczenie go do wtasnego warsztatu pracy wymaga od nauczyciela całkowitej 
zmiany w myśleniu o edukacji dziecka z niepetnosprawnościa intelektualna. Klocki pod tym względem niezwykle wspomagaja proces nauczania".

Z pewnością każdy kreatywny nauczyciel dostrzegłby w systemie kolejne możliwości wykorzystania i stymulowania innych obszarów rozwoju.

W metodyce nauczania trudno podać przykład narzędzia lub systemu, którego użycie nie wiązałoby się z pewnymi ograniczeniami i niedoskonałościami. Pierwszą niedogodnością, która wynika z budowy samego narzędzia, są użyte w nim kolory. Na problem ten zwrócił uwagę Pan Arkadiusz:

W mojej ocenie ograniczenie systemu dotyczy kolorystyki klocków zupetnie rozmijającej się z kolorystyka w innych systemach (Stern Structural Arithmetic). (...) W takim przypadku rozbieżności kolorystyczne moga zakłócić przebieg operacji arytmetycznych u dziecka i istotnie zdeterminować wynik liczenia.

Na zupełnie inne niedopracowanie systemu zwraca uwagę Pani Beta:

Patrzac na matematykę z punktu widzenia programu, a nie z jej praktycznego wykorzystania, to ja pracę z systemem muszę uzupetniać elementami "Dziecięcej matematyki”. Mam na myśli tutaj naukę kierunków, orientacji przestrzennej i lateralizacji. Brakuje w Numiconie ćwiczeń uwzględniających kierunki, przestrzeń, stronę prawa i lewa, a w geometrii takie myślenie jest bardzo potrzebne.

Pani Beata zwraca uwagę na jeszcze jedno, bardzo znaczące ograniczenie systemu:

Jak miałam zajęcia z młodzieża szkót specjalnych z Zespołem Downa, to w momencie kiedy przeszli już pewien etap szkolny, nie chca podejmować się pracy Numiconem. Klocki wydaja im się czymś niepoważnym, czymś infantylnym. Często traktuja go jako zabawkę i nie widza w nim narzędzia do pracy i nauki matematyki, nawet jeżeli sprawia im ona problemy.

Niechęć starszych uczniów do kształtów jest dużym utrudnieniem dla nauczycieli, ponieważ zamyka możliwości wprowadzenia metody wśród młodzieży niepełnosprawnej intelektualnie. Ostatnim mankamentem systemu jako narzędzia, który można wyłonić z wypowiedzi badanych, jest waga klocków. Na problem ten uwagę zwrócił Pan Arkadiusz:

Kolejnym ograniczeniem może być stabe wyeksponowanie w strukturze klocka jego ciężaru. Szczególnie dzieci z niepetnosprawnościa ruchowa mogłyby odnieść większą korzyść w nauczaniu, gdyby różnice w ciężarze między klockami były bardziej wyczuwalne.

Pani Iwona odniosła się również do podręczników i zeszytów ćwiczeń wydawnictwa Oxford University Press, przeznaczonych do pracy z systemem Numicon:

Niestety materiały, które zamówiliśmy jako Fundacja z Oxford University Press, kosztowaty bardzo dużo jak na nasze polskie realia i nie spetnity naszych oczekiwań. Materiały w żaden sposób nie są dostosowane do możliwości uczniów z niepetnosprawnością intelektualną. Jest niewiele powtórzeń i utrwalania materiału. Poziom jest po prostu za wysoki. 
Badani zwrócili też uwagę na problemy z wprowadzeniem systemu Numicon do polskiej edukacji. Jednym z takich zjawisk, o którym wspominali wszyscy badani, jest niska popularność metody w Polsce. Wszyscy badani podkreślali brak zainteresowania wśród polskich nauczycieli i placówek systemem Numicon. Tak wypowiedział się na ten temat Pan Arkadiusz:

Od 2010 roku pracuję w systemie Numicon systematycznie. (..) Większość spotkań ma charakter indywidualny, co wynika z niewielkiego zainteresowania nauczycieli tym, aby zorganizować nauczanie systemowo od poczattku i prowadzić je do ostatniego etapu. Potrzebujemy w moim odczuciu nie tylko czasu, ale i pewnej mentalnej dekonstrukcji, aby w Polsce między innymi ten system znalazł uznanie w gronie tych najważniejszych osób w edukacji, to znaczy nauczycieli.

Pani Beata odniosła się do swojego doświadczenia jako nauczyciel matematyki:

Kiedy ustyszałam o metodzie Numicon miałam możliwość ja poznać dzięki Fundacji i tam też uzyskać informację. Jednak poza Fundacją tylko firma Moje Bambino prowadzi szkolenia dla nauczycieli z tego zakresu. Niestety, odnosza się one do dzieci petnosprawnych, dlatego brakuje specjalistycznych szkoleń pod katem pracy z dziećmi niepetnosprawnymi.

Szkolenia są coraz popularniejszą forma kształcenia nauczycieli, dlatego ograniczony dostęp do nich może być przyczyną porzucenia zainteresowania metodą. Pani Iwona oprócz ograniczonej dostępności szkoleń wspomniała również o znikomej ilości materiałów:

W Polsce jest firma dystrubująca klocki, ale niestety, nawet jeżeli nauczyciel je zamówi, nie ma żadnego źródła, z którego może czerpać wiedzę. Brakuje podręcznika metodycznego czy zeyszytu ćwiczeń zaadaptowanego do pracy z dziećmi niepetnosprawnymi intelektualnie.

Pan Arkadiusz jako pracownik naukowy odniósł się z kolei do prac naukowych i źródeł metodycznych:

Warto wspomnieć, że jeszcze do dziśl liczba publikacji o tym systemie w języku polskim jest śladowa. Z jednej strony mamy zagraniczne publikacje naukowe oraz bogate doświadczenie pedagogiczne naszych zagranicznych kolegów, a z drugiej strony jałowa pod tym względem przestrzeń edukacyjna szkolnictwa dla uczniów o specjalnych potrzebach edukacyjnych w naszym kraju.

To kolejny powód, dla którego nauczyciele polscy mogą rezygnować z wdrożenia zmian i niechętnie podejmować się zgłębiania zagadnienia metody.

Analiza wszystkich wypowiedzi z perspektywy wyróżnionych wcześniej obszarów, a więc możliwości i ograniczeń, jakie upatrują badani w metodzie Numicon, pozwoliła na podsumowanie i zestawienie ich $w$ formie tabeli, dotyczących odpowiednio możliwości systemu Numicon (zob. tab. 6) i jego ograniczeń (zob. tab. 7). 
Tabela 6. Dane jakościowe - możliwości, jakie upatrują badani w metodzie Numicon

\begin{tabular}{|c|c|}
\hline Obszar analizy & Uzyskane dane \\
\hline $\begin{array}{l}\text { Struktura } \\
\text { narzędzia } \\
\text { (kształty, kołki) }\end{array}$ & $\begin{array}{l}\text { - wizualizacja liczb, w tym wykorzystanie kanału wzrokowego do reprezen- } \\
\text { towania liczb (wykorzystanie zarówno koloru, jak i specyficznego kształtu); } \\
\text { - multisensoryczne oddziaływanie metody poprzez włączenie dotyku } \\
\text { w proces budowania obrazu liczby w umyśle; } \\
\text { - oparcie systemu nauczania na konkrecie, silne wykorzystanie enaktywnej } \\
\text { reprezentacji liczby oraz stałość materiału, niezmienność kształtów; } \\
\text { - obrazowość wykonywanych na klockach operacji, m.in. dopełniania liczb, } \\
\text { oraz konkretne algorytmy działań arytmetycznych; } \\
\text { - możliwość manipulowania klockami pomimo obniżonej sprawności } \\
\text { motorycznej; } \\
\text { - wykorzystanie klocków w ćwiczeniach grafomotorycznych. }\end{array}$ \\
\hline Planowanie zajęć & $\begin{array}{l}\text { - pozostawianie nauczycielowi dużego pola do modyfikacji i wprowadzania } \\
\text { własnych pomysłów wykorzystania kształtów, tworzenia gier edukacyjnych; } \\
\text { - systemowa struktura metody oraz jasno określone etapy systemu Numicon; } \\
\text { - możliwość stymulacji innych funkcji umysłowych i poznawczych, m.in. } \\
\text { kategoryzacja, szeregowanie, układanie sekwencji, stymulowanie pamięci } \\
\text { słuchowej i wzrokowej; } \\
\text { - kompatybilne rozwiązanie wprowadzania pojęcia czasu. }\end{array}$ \\
\hline $\begin{array}{l}\text { Motywacja } \\
\text { uczniów }\end{array}$ & $\begin{array}{l}\text { - atrakcyjność materiału dla dzieci, a co za tym idzie wzbudzanie motywacji } \\
\text { do nauki matematyki; } \\
\text { - niwelowanie negatywnych skojarzeń odnoszących się do matematyki } \\
\text { wśród uczniów. }\end{array}$ \\
\hline
\end{tabular}

Źródło: Opracowanie własne.

Poza wymienionymi wyżej możliwościami metody badani wskazywali ograniczenia, jakie dostrzegają lub przewidują podczas wprowadzania metody do edukacji matematycznej dzieci z niepełnosprawnością intelektualną (por. tab. 7).

Tabela 7. Dane jakościowe - ograniczenia, jakie upatrują badani w metodzie Numicon

\begin{tabular}{|l|l|}
\hline \multicolumn{1}{|c|}{ Obszar analizy } & \multicolumn{1}{c|}{ Uzyskane dane } \\
\hline $\begin{array}{l}\text { Sposób zaprojekto- } \\
\text { wania narzędzia }\end{array}$ & $\begin{array}{l}\text { - wykorzystana w kształtach kolorystyka, która nie jest tożsama z kolorystyką } \\
\text { innych matematycznych systemów multisensorycznych; } \\
\text { - waga klocków nieprecyzyjnie oddająca różnicę między nimi. }\end{array}$ \\
\hline Struktura systemu & $\begin{array}{l}- \text { brak ćwiczeń orientacji przestrzennej i lateralizacji; } \\
- \text { niedostosowanie dostępnych materiałów do potrzeb i możliwości dzieci } \\
\text { niepełnosprawnych intelektualnie. }\end{array}$ \\
\hline Motywacja uczniów & - niechęć do systemu wśród młodzieży (jego infantylny charakter). \\
\hline $\begin{array}{l}\text { Numicon w pol- } \\
\text { skiej edukacji } \\
\text { matematycznej }\end{array}$ & $\begin{array}{l}\text { niskie zainteresowanie metodą wśród nauczycieli, nieproporcjonalne } \\
\text { do zainteresowania wśród rodziców; } \\
- \text { brak programu, podręcznika metodycznego; } \\
- \text { brak profesjonalnych szkoleń przygotowujących do pracy z systemem } \\
\text { Numicon. }\end{array}$ \\
\hline
\end{tabular}

Źródło: Opracowanie własne. 


\section{Zakończenie}

W analizie badań ewaluacyjnych system Numicon jawi się jako narzędzie bardzo atrakcyjne dla nauczycieli i uczniów, oparte na określonym systemie, przy jednoczesnym zachowaniu dużej swobody w projektowaniu postępowania edukacyjnego. Wyniki badań ilościowych udowadniają wysoką efektywność systemu w pracy zarówno z uczniami pełnosprawnymi, jak i z uczniami ze specjalnymi potrzebami edukacyjnymi. Biorąc pod uwagę doświadczenia brytyjskie, Numicon w szkole polskiej może być ogromną szansą dla dzieci ze specjalnymi potrzebami edukacyjnymi w zakresie nauki matematyki. Dzięki szerokiemu spektrum zastosowania system Numicon może również okazać się doskonałym rozwiązaniem metodycznym dla klas integracyjnych, gdzie kształty Numicon mogą być wykorzystywane w pracy z całą klasą, niezależnie od poziomu dzieci. Praca z wykorzystaniem systemu Numicon może nie tylko poszerzyć zakres umiejętności matematycznych w grupie uczniów ze specjalnymi potrzebami edukacyjnymi, ale także podnieść ich motywację do pracy oraz poczucie pewności siebie. $\mathrm{W}$ przypadku dzieci niepełnosprawnych intelektualnie wymienione wyżej efekty pracy z systemem Numicon są niezbędnym krokiem w kierunku samodzielności.

Niestety, z badań na gruncie polskim wynika, że przed szerokim wdrożeniem systemu w polską edukację matematyczną stoi wiele barier. Większość z nich dotyczy nie tyle konstrukcji systemu edukacji w Polsce, ale postaw nauczycieli, którzy niechętnie podejmują się zmian w swojej praktyce dydaktycznej. Wnioskując z opracowanego materiału, drogami prowadzącymi do zmian i szansy dla systemu Numicon w Polsce jest przygotowanie odpowiednich podręczników metodycznych i poszerzenie oferty szkoleń, a także kontynuacja badań ewaluacyjnych na temat pracy z systemem wśród polskich uczniów.

\section{Bibliografia}

Anderson O.R. (1997), A Neurocognitive Perspective on Currant Learning Theory and Science Instructional Strategies, „Science Education”, nr 1.

Bobryk J. (1996), Akty świadomości i procesy poznawcze, Wrocławska Drukarnia Naukowa, Wrocław.

Bruner J. (1978), Poza dostarczone informacje: Studia z psychologii poznawania, PWN, Warszawa.

Cambridge Primary Mathematics Framework (2011), http://fdslive.oup.com/www.oup.com/ oxed/primary/maths/numicon/Numicon_curricula_and_the_cambridge_maths_framework. pdf?region=international [dostęp: 16.05.2017].

Cieszyńska-Rożek J. (2013), Metoda krakowska wobec zaburzeń rozwoju dzieci. Z perspektywy fenomenologii, neuorbiologii i językonawstwa, Centrum Metody Krakowskiej, Kraków.

Coleman K. (2003), Using Numicon - a report from a special school, „Down Syndrome News and Update", nr 3. 
Dylak S. (2000), Konstruktywizm jako obiecująca perspektywa w kształceniu nauczycieli [w:] Wspótczesność, a kształcenie nauczycieli, H. Kwiatkowska, T. Lewowicki, S. Dylak (red.), Wyższa Szkoła Pedagogiczna ZNP, Warszawa.

Elkind D. (1967), Piaget's Conservation Problems, „Child Development”, t. 38, nr 1.

Ewan C., Mair C. (2002), Wiltshire Pilot Projekt - Numicon, (March-July 2001), „Down Syndrome News and Update", nr 2(1).

Filipiak E. (2011), Z Wygotskim i Brunerem w tle: Stownik pojęć kluczowych, Wydawnictwo Uniwersytetu Kazimierza Wielkiego, Bydgoszcz.

Fosnot T.C. (1996), Constructivism. Theory, Perspectives, and Practice, Teachers College Press, New York.

Gołębniak B. (2007), Program szkolny [w:] Pedagogika. Podręcznik akademicki, t. 2, Z. Kwieciński, B. Śliwerski (red.), PWN, Warszawa.

Gruszczyk-Kolczyńska E. (1994), Dzieci ze specyficznymi trudnościami w uczeniu się matematyki, Wydawnictwa Szkolne i Pedagogiczne, Warszawa.

Klus-Stańska D. (2010), Dydaktyka wobec chaosu pojęć i zdarzeń, Wydawnictwo Akademickie ŻAK, Warszawa.

Kubiak D. (2017), Wprowadzenie metody Numicon na etapie nauczania przedszkolnego i wczesnoszkolnego dzieci niepetnosprawnych intelektualnie w doświadczeniach nauczycieli, Uniwersytet Gdański, Gdańsk (maszynopis).

Leeds Primary National Strategy Team [2005], Multi-sensory approach to the teaching and learning of mathematics, Leeds.

Doncaster LA (2008), Multi-sensory Mathematics for Wave 3 Intervention, https://www.numicon.co.nz/uploads/66441/files/Doncaster-Case-Study-16090.pdf [dostęp: 16.05.2017].

Nye J., Buckley S., Bird G. (2002), Evaluating the Numicon system as a tool for teaching number skills to children with Down syndrome, "Down Syndrome News and Update”, nr 5.

Semadeni Z. (2015), Matematyka w edukacji początkowej - podejście konstruktywistyczne [w:] Matematyczna edukacja wczesnoszkolnna. Teoria i praktyka, Z. Semadeni, E. Gruszczyk-Kolczyńska, G. Terliński, B. Bugajska-Jaszczołt, M. Czajkowska (red.), Wydawnictwo Pedagogiczne ZNP, Kielce.

Semadeni, Z. (2016), Podejście konstruktywistyczne do matematycznej edukacji wczesnoszkolnej, Ośrodek Rozwoju Edukacji, Warszawa, https://www.ore.edu.pl/materiay-do-pobrania-74508/matematyka?download=3675:podejscie-konstruktywistyczne-do-matematycznej-edukacji-wczesnoszkolnej [dostęp: 14.05.2017].

Spitzer M. (2011), Jak uczy się mózg, PWN, Warszawa.

S pringer, S. (2004), Lewy mózg, prawy mózg. Z perspektywy neurobiologii poznawczej, Prószyński i S-ka, Warszawa.

Szulman-Wardal A., Mański A. (2014), System Numicon w nauczaniu i rehabilitacji dziecka z zespołem Downa - aplikacje praktyczne [w:] Przepis na rehabilitację. Metodologie oraz metody w badaniach i transdyscyplinarnej praktyce rehabilitacyjnej, W. Otrębski, G. Więcek (red.), Wydawnictwo KUL, Lublin.

Tacon R., Atkinson R., Wing T. (2004), Learning about numbers with patterns: using structured visual imagery (Numicon) to teach arithmetic, BEAM Education, London.

Wing T., Tacon R. (2007), Teaching number skills and concepts with Numicon material, „Down Syndrome Research and Practice", nr 12(1). 